\title{
PREDICTION OF TUBING-CASING ANNULUS OVERFLOWS BASED ON THE
} LABORATORY STUDIES RESULTS

•. сс дников, . . с чев, . . рошев

V. I. Rassadnikov, E. A. Usachev, T. V. Grosheva
юменское отделение « ургут
нефть»
« ургутнефтег з», г.
юмень
етрофизических исследов ний
юменского отделения
ургут
нефть, 2. юмень

лючевые слов : дгезия; цементный к мень; глинист я корк ; буровой р створ Key words: adhesion; cement stone; mud cake; drilling mud 
репление скв жин, р зрез которых предст влен пород ми с р зличными деформ ционно-прочностными и петрофизическими х р ктеристик ми, отлич ющимися фильтр ционно-емкостными свойств ми и имеющими $\mathrm{p}$ зличный $\mathrm{x} p \mathrm{k}-$ тер н сыщ ющего гент, является кту льной з д чей, от решения которой з висит долговечность скв жины и к чество получ емой продукции.

сновной $з$ д чей цементиров ния скв жин является предотвр щение межпл стовых перетоков, ее невыполнение, в свою очередь, приводит к обводнению скв жины уже н н ч льном эт пе эксплу т ции.

дним из н иболее зн чимых ф кторов, влияющих н дгезионное сцепление цементного к мня с породой, является н личие фильтр ционной корки. ри бурении скв жин н полимерных буровых р створ х н стенк х скв жины, в интерв л х прониц емых пород, обр зуется глинист я корк , котор я сниж ет объем отфильтров нной из цементного р створ жидкости и в определенной степени ухудш ет дгезию цемент с породой.

ля прогнозиров ния интерв лов возможных перетоков были проведены л боp торные p боты, н пр вленные н определение прочности конт кт цемент с p зличными тип ми пород вследствие недост точной дгезии. еобходимо т кже отметить, что величин дгезии является косвенным пок з телем при определении интерв л возможных перетоков, поэтому основн я цель р бот 3 ключ л сь в определении д вления прорыв модели пл стовой воды в месте конт кт пород цементный к мень.

к честве объектов исследов ний были использов ны х р ктерные для р зрез месторождения обр зцы пород, предст вленные ргиллит ми, левролит ми, мелкозернистым левритистым песч ником (т бл. 1). ля испыт ния были взяты обр зцы цемент м рок -I-G-CC-1 и

блии 1

р тк ялитологическ я $х$ р ктеристик обр зцов

\begin{tabular}{|c|c|c|}
\hline $\begin{array}{l}\text { № } \\
\text { п/ா }\end{array}$ & итологическое опис ние & $\begin{array}{l}\text { пр (гелий) } \\
\text { мкм }^{2} * 10^{-3}\end{array}$ \\
\hline 1 & ргиллит левритистый & 0,0027 \\
\hline 2 & ргиллит левритистый & 0,0693 \\
\hline 3 & $\begin{array}{l}\text { левролит мелкозернистый с ч стыми н мыв ми } \\
\text { глинистого м тери л }\end{array}$ & 0,3384 \\
\hline 4 & левролит мелкозернистый глинистый & 0,0131 \\
\hline 5 & левролит мелкозернистый глинистый & 0,001 \\
\hline 6 & левролит мелкозернистый глинистый & 0,0049 \\
\hline 7 & левролит мелкозернистый глинистый & 0,0089 \\
\hline 8 & левролит мелкозернистый глинистый & 0,004 \\
\hline 9 & левролит мелкозернистый глинистый & 0,0238 \\
\hline 10 & $\begin{array}{l}\text { есч ник мелкозернистый с глинистым цементом } \\
\text { с ч стыми н мыв ми глинистого м тери л }\end{array}$ & 0,0391 \\
\hline 11 & $\begin{array}{l}\text { есч ник мелкозернистый с глинистым цементом } \\
\text { с ч стыми н мыв ми глинистого м тери л }\end{array}$ & 0,0262 \\
\hline 12 & есч ник мелкозернистый левритистый с глинистым цементом & 0,0571 \\
\hline 13 & есч ник мелкозернистый левритистый с глинистым цементом & 0,001 \\
\hline 14 & есч ник мелкозернистый левритистый с глинистым цементом & 0,001 \\
\hline 15 & есч ник мелкозернистый нефтен сыщенный однородный & 1,951 \\
\hline 16 & $\begin{array}{l}\text { есч ник мелкозернистый нефтен сыщенный с тонкими слойк ми } \\
\text { ргиллит }\end{array}$ & 1,6309 \\
\hline 17 & $\begin{array}{l}\text { есч ник мелкозернистый левритистый сл бонефтен сыщенный } \\
\text { слойк ми без нефтен сыщенности }\end{array}$ & 1,0104 \\
\hline
\end{tabular}

\section{2}


ост вленн я цель р боты определил следующий порядок проведения экспериментов. тбир лись обр зцы кернового м тери л $30 * 30$ из интерв лов 3 лег ния ргиллитов, левролитов, прониц емой ч сти продуктивного пл ст 2 , углистых отложений. керн х для моделиров ния р ди льной фильтр ции высверлив лось отверстие ди метром 12 мм.

бр зцы р зличных типов пород помеш лись в кернодерж тель уст новки FDTES 100-140, и созд в лись н ч льные пл стовые условия, горное д вление и темпер тур .

целью н мыв корки в циркуляционном режиме прок чив ли применяемый полимерный р створ, при этом величин циклической репрессии сост влял 2-4 , что х р ктерно для режим бурения и спускоподъемных опер ций.

3 ключение моделиров лся процесс смыв корки, для чего через колонку кернов в циркулирующем режиме прок чив л сь буферн я жидкость. осле моделиров ния процесс н мыв и смыв корки, обр зцы з лив лись исследуемым цементным р створом и помещ лись в водяную к меру высокого д вления и темпер туры н 24 ч с для формиров ния цементного к мня.

о истечении з д нного времени обр зцы помещ лись в термоб ню до проведения экспериментов по определению д вления прорыв , $з$ тем поочередно уст н влив лись в кернодерж тель уст новки, в которой созд в ли пл стовые условия и определяли величину д вления прорыв пл стовой воды в месте конт кт пород — цементный к мень (т бл. 2).

езульт ты исследов ний

\begin{tabular}{|c|c|c|c|c|}
\hline ород & $\begin{array}{c}\text { рониц емость, } \\
\text { м }\end{array}$ & $\begin{array}{c}\text { личие } \\
\text { глинистой } \\
\text { корки }\end{array}$ & $\begin{array}{c}\text { р ктеристик } \\
\text { конт кт }\end{array}$ & $\begin{array}{c}\text { езульт ты } \\
\text { проверки н } \\
\text { герметичность }\end{array}$ \\
\hline $\begin{array}{c}\text { ргиллит } \\
\text { левритистый }\end{array}$ & $0,003-0,07$ & ет & олный & ерметично \\
\hline $\begin{array}{c}\text { левролит } \\
\text { мелкозернистый } \\
\text { глинистый }\end{array}$ & $\begin{array}{c}0,001 \\
0,3-0,5\end{array}$ & $\begin{array}{c}\text { ет } \\
\text { сть }\end{array}$ & $\begin{array}{c}\text { олный } \\
\text { стичный }\end{array}$ & $\begin{array}{c}\text { ерметично } \\
\text { егерметично } \\
\text { есч ник } \\
\text { мелкозернистый }\end{array}$ \\
\hline
\end{tabular}

blводы

1. о результ т м л бор торных исследов ний относительно прочный конт кт цемент с породой обр зуется в непрониц емых обр зц х.

2. ри н личии д же незн чительной (от 0,3 м ) прониц емости в породе происходит н мыв фильтр ционной корки бурового р створ , котор я не уд ляется при применении в к честве буферной жидкости технической воды, при этом отсутствует прямой конт кт цемент - горн я пород .

3. личие фильтр ционной корки н прониц емой горной породе зн чительно сниж ет прочность конт кт цемент - глинист я корк -пород . рорыв конт кт происходит по глинистой корке, о чем свидетельствует н личие перетоков д же при небольших д влениях.

4. ценить прочность конт кт цемент с углями и углистыми пород ми по н стоящей методике не уд лось из-з р зрушения обр зцов в процессе их приготовления в связи с хрупкостью, тем не менее отсутствие прониц емости в углистых пропл стк х д ет возможность предположить н личие хорошего конт кт цемент - горн я пород .

ведения об втор $x$

сс дников л димир в нович, $з$ меститель директор по бурению юменского отделе-
Information about the authors

Rassadnikov V. I., Director Deputy head for Drilling of Tyumen branch of «SurgutNIPIneft», 
ния « ургут

нефть $8(3452) 687225$

Rassadnikov_VI@surgutneftegas.ru

с чев вгений ндреевич, $\kappa$. . н., н ч льник н учно-исследов тельского отдел определения геомех нических свойств горных пород,

етрофизических исследов ний юменского отделения ургут нефть, тел. 8(3452)687382

рошев тьян икторовн, ведущий н учный сотрудник, определения геомех нических свойств горных пород, петрофизиче-

ских исследов ний, "ургут нефть», тел. 8(3452)687447
OJSC «Surgutneftegas», phone: 8(3452)687225, e-mail: Rassadnikov_VI@surgutneftegas.ru

Usachev E. A., Candidate of Science in Engineering, head of the research department «Study of geomechanical properties of rocks», Researchproduction complex for petrophysical studies, Tyumen branch of «SurgutNIPIneft», OJSC «Surgutneftegas», phone: 8(3452)687382

Grosheva $\boldsymbol{T}$. $\boldsymbol{V}$., leading research worker of the research department «Study of geomechanical properties of rocks», Research-production complex for petrophysical studies, Tyumen branch of «SurgutNIPIneft», OJSC «Surgutneftegas», phone: 8(3452) 687447 